\title{
Climatic implications of reconstructed early-mid Pliocene equilibrium-line altitudes in the McMurdo Dry Valleys, Antarctica
}

\author{
A.G. KRUSIC, ${ }^{1 *}$ M.L. PRENTICE, ${ }^{2}$ J.M. LICCIARDI ${ }^{3}$ \\ ${ }^{1} 255$ S. Greenbush Road, Orangeburg, NY 10962, USA \\ E-mail: anna@krusic.org \\ ${ }^{2}$ Indiana Geological Survey and Department of Geological Sciences, Indiana University, \\ 611 N. Walnut Grove, Bloomington, IN 47405, USA \\ ${ }^{3}$ Department of Earth Sciences, University of New Hampshire, Durham, NH 03824, USA
}

\begin{abstract}
Early-mid Pliocene moraines in the McMurdo Dry Valleys, Antarctica, are more extensive than the present alpine glaciers in this region, indicating substantial climatic differences between the early-mid Pliocene and the present. To quantify this difference in the glacier-climate regime, we estimated the equilibrium-line altitude (ELA) change since the early-mid Pliocene by calculating the modern ELA and reconstructing the ELAs of four alpine glaciers in Wright and Taylor Valleys at their early-mid Pliocene maxima. The area-altitude balance ratio method was used on modern and reconstructed early-mid Pliocene hypsometry. In Wright and Victoria Valleys, mass-balance data identify present-day ELAs of $800-1600 \mathrm{~m}$ a.s.I. and an average balance ratio of 1.1. The estimated ELAs of the much larger early-mid Pliocene glaciers in Wright and Taylor Valleys range from 600 to $950 \pm 170 \mathrm{~m}$ a.s.I., and thus are $250-600 \pm 170 \mathrm{~m}$ lower than modern ELAs in these valleys. The depressed ELAs during the early-mid-Pliocene most likely indicate a wetter and therefore warmer climate in the Dry Valleys during this period than previous studies have recognized.
\end{abstract}

\section{INTRODUCTION}

The magnitude of climate warmth in Antarctica during the early-mid Pliocene and the associated size of the Antarctic ice sheet are fundamental questions about the causes and impacts of Pliocene global warmth (Cronin and others, 2005; Dowsett and others, 2005). The Antarctic glacierclimate system's response to past warming also provides important insight into how future warmer global air temperatures might influence the Antarctic environment. The common wisdom from the McMurdo Dry Valleys (MDV) of Antarctica is that during the early-mid Pliocene, Antarctica was no warmer than it is now and ice volume was about the same (Denton and others, 1993; Sugden and others, 1995; Lewis and others, 2006). Evidence for this 'stable' view is the presence of Miocene-age volcanic ashes interpreted to be in situ (Marchant and others, 1996) and still hardly modified by glacier overriding. However, conditions warmer than present in the McMurdo Sound region in the early-mid Pliocene have been inferred from the oxygen isotopic composition of foraminifers and scallops in fjord deposits in the MDV, indicating fresher and warmer $\left(0-3^{\circ} \mathrm{C}\right)$ fjord bottom water than water in the Ross Sea today (Prentice and others, 1993). Moreover, the fossil content of sediments from several sectors of coastal Antarctica (e.g. Nothofagus wood, beetles, and shells) has been interpreted as evidence for a possible warming of $20^{\circ} \mathrm{C}$ relative to modern in the early Pliocene (Webb and other, 1984; Ashworth and Kuschel, 2003). The mountains of the MDV contain many alpine glaciers whose fluctuations since the late Miocene are documented on the ice-free slopes of the trunk valleys. Here we reconstruct the early-mid Pliocene equilibrium-line altitudes (ELAs) of four alpine glaciers (Fig. 1) and compare these values to modern ELAs.

*Present address: Djurgårdsvägen 221, SE-115 21 Stockholm, Sweden.
Alpine glacial deposits of Pleistocene age in both Wright and Taylor Valleys are narrow boulder-belt moraines (Hall and others, 1993; Wilch and others, 1993a; Prentice and Krusic, 2005). However, in the early-mid Pliocene, alpine glaciers were at times substantially advanced compared to today. The oldest glacial deposits that can be reached by hand-dug excavation dated to $>3.7 \pm 0.1 \mathrm{Ma}$ (Hall and others, 1993) and occur beyond the boulder belts (Prentice and Krusic, 2005). Maintenance of lower and larger alpine glaciers in the MDV required a different climate, most likely an increase in precipitation. Higher Pliocene precipitation totals are plausible only if accompanied by higher temperatures, which would have supported more atmospheric moisture. Therefore, our hypothesis is that the early-mid Pliocene ELA was lower than the modern ELA, indicative of a warmer and wetter climate in the early-mid Pliocene than the present.

The alpine glaciers in the MDV are polar, meaning they are cold-based year round and in equilibrium with the polar desert climate (Holdsworth and Bull, 1970; Chinn, 1991). Mean annual temperature at sea level ranges between -15 and $-20^{\circ} \mathrm{C}$, and mean annual precipitation is $<100 \mathrm{~mm}$ w.e. (Chinn, 1991; Fountain and others, 1999). Glacier ablation is dominated by sublimation (Chinn, 1994; Fountain and others, 1998). The accumulation-area ratio (AAR), a predefined ratio of the glacier's area of positive net annual mass balance, was calculated by Chinn (1994) to be 0-0.4 for the polar glaciers in the MDV, a ratio that reflects the low ablation rate (Porter, 1975).

Moisture is mainly from the Ross Sea and is limited by low air temperature (Dort, 1970; Chinn, 1996; Fountain and others, 1998). Orographic barriers influence the distribution of precipitation, and glacier accumulation is dominated by redistributed wind-blown snow (Chinn, 1996; Fountain, 1996, 1998). During the most recent glacial maximum in the region, grounded ice in the 


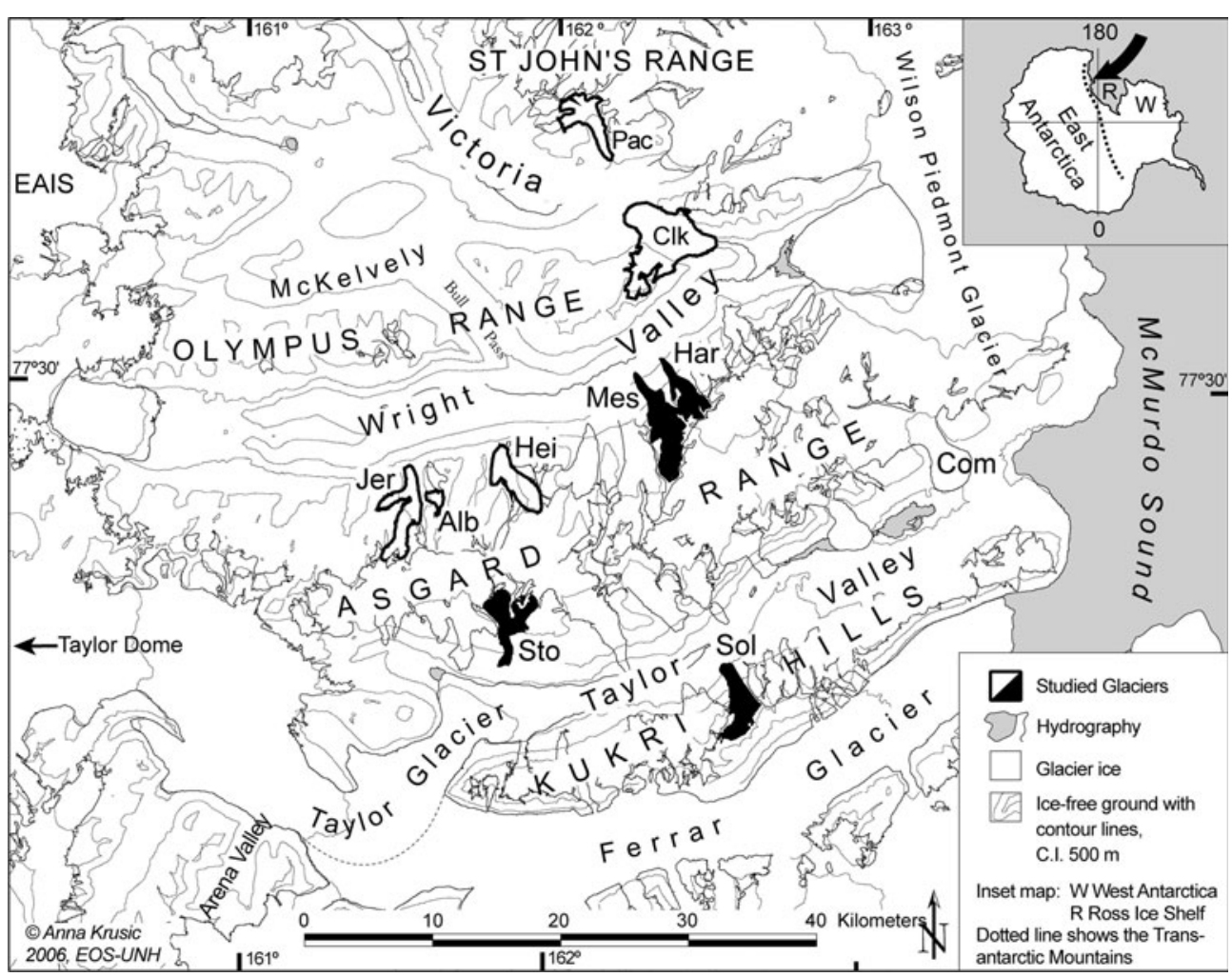

Fig. 1. The McMurdo Dry Valleys, Antarctica. Reconstructed alpine glaciers (black) are: Meserve (Mes), Hart (Har), Stocking (Sto) and Sollas (Sol) glaciers. Mass-balance measurements were available for the following glaciers: Packard (Pac), Clark (Clk), Jeremy Sykes (Jer), Alberich (Alb), Heimdall (Hei) and Meserve (Mes) glaciers. Modern ELA from Commonwealth Glacier (Com) in Taylor Valley is included in Figure 2. The East Antarctic ice sheet is denoted EAIS. C.I.: contour interval.

Ross Sea lowered precipitation reaching the MDV, causing the climate in the valleys to be much drier and cooler than today (Denton and others, 1989). Consequently, alpine glaciers, as well as Taylor Glacier (a valley glacier), were smaller and ELAs were assumed higher than today (Denton and others, 1989).

We selected four alpine glaciers, two in Wright Valley and two in Taylor Valley, with extensive early-mid Pliocene moraine sequences for paleo-ELA reconstruction (Fig. 1) (Krusic, 2006). For these glaciers, modern and early-mid Pliocene ELA was estimated to assess the ELA difference, $\triangle \mathrm{ELA}$, between these times. Modern mass-balance measurements are available for one of the reconstructed glaciers, Meserve Glacier, and for five other glaciers in Wright and Victoria Valleys (Fig. 1). The mass-balance data include specific summer and winter balance values collected over mass-balance seasons (1972/73 to 1982/83, with data from one to four glaciers per season) (Chinn, 1979, 1980, 1981, 1983).

\section{METHODS}

\section{Early-mid Pliocene glacier reconstruction}

The early-mid Pliocene glacier margins were reconstructed by following center lines and crests of lateral moraines interpreted as belonging to the oldest alpine glaciations (Hall and others, 1993, 1997; Prentice and Krusic, 2005), representing maximum possible early-mid Pliocene glaciers. Above the elevation of the highest alpine deposits, the boundaries were identified by break-of-slopes in the bedrock interpreted from aerial photographs and topographical profiling in ArcGIS. We adjusted the margins to be symmetrical where laterally supporting landforms were missing.

The glacier-margin elevations were estimated from moraine-crest elevations obtained by lidar and trimlines interpreted from inflections in the bedrock topography (Krusic, 2006). Contour lines with $100 \mathrm{~m}$ intervals were interpolated over the paleo-glacier surface, drawn in straight lines to avoid bias of the ELA position. The largest source of error in the reconstructed hypsometry was estimated to be in the accumulation area where the early-mid Pliocene glacier surface elevation was approximated. In the ablation zone, the error in reconstructed surface elevation originates in the use of the modern height/ width ratio, but we assume this error is less significant due to the defining surficial geology. We assume that the larger Meserve, Hart and Stocking glaciers did not merge with any other glaciers.

\section{Modern mass balance and ELA}

The modern ELA $\left(E_{L} A_{b n}\right)$ was calculated for the six glaciers by digitizing point mass-balance measurements into a Geographic Information System (GIS) and contouring the data. We then calculated the modern ELA through interpolation of the $B_{\mathrm{n}}$-elevation pairs just below and above $B_{\mathrm{n}}=0$. Modern mass-balance data were used to calculate balance ratio $(B R$, the ratio between the ablation gradient and the accumulation gradient) and AAR. The BR is averaged to obtain a regional value for the reconstruction of early-mid Pliocene ELA for the other three glaciers (Hart, Sollas and Stocking glaciers). 
Table 1. ELA and average AAR and BR calculated from the 19701980 mass-balance data in the MDV. The last columns show estimated ELA and deviations from actual ELA $b_{\mathrm{n}}$ based on the average $B R$ value

\begin{tabular}{|c|c|c|c|c|c|}
\hline \multirow[t]{2}{*}{ Glacier } & $\begin{array}{l}\text { Average } \\
\text { ELA } b_{\mathrm{n}}\end{array}$ & AAR & $B R$ & $\mathrm{ELA}_{\mathrm{BR}}=1.1$ & \multirow[t]{2}{*}{$\begin{array}{c}\text { Difference } \\
\text { between ELA } b_{\mathrm{r}} \\
\text { and } \mathrm{ELA} \mathrm{A}_{\mathrm{BR}=1.1}\end{array}$} \\
\hline & ma.s.l. & & & ma.s.l. & \\
\hline Alberich & 1591 & 0.58 & 0.56 & 1578 & -13 \\
\hline Heimdall & 1478 & 0.46 & 0.61 & 1454 & -24 \\
\hline J. Sykes & 1500 & 0.56 & 0.83 & 1478 & -22 \\
\hline Meserve & 1233 & 0.75 & 1.00 & 1221 & -12 \\
\hline Packard & 966 & 0.69 & 2.45 & 1030 & +64 \\
\hline Average & 1260 & 0.61 & 1.1 & \multicolumn{2}{|c|}{ ELA $2 \sigma: 18 \mathrm{~m}^{*}$} \\
\hline
\end{tabular}

*Packard Glacier excluded

\section{Early-mid Pliocene ELA estimation}

We calculated early-mid Pliocene ELA with the areaaltitude balance ratio (AABR) method and maximum elevations of lateral moraines (MELM) (Andrews, 1975; Furbish and Andrews, 1984; Kaser and Osmaston, 2002). First introduced by Kurowski (1891) and later developed by Osmaston (1975) and others (Furbish and Andrews, 1984; Kaser and Osmaston, 2002), the AABR method takes into account glacier hypsometry and shape of the mass-balance gradient. This gradient is defined as the change of the net specific mass balance $\left(b_{\mathrm{n}}\right)$ with altitude. The AABR method assumes glacier equilibrium, linear ablation and accumulation mass-balance gradients (mass balance vs altitude). We further assume that the AABR method is applicable in both the modern and the early-mid Pliocene environment and that the laws of glacier dynamics are the same. We estimate that the uncertainties of the hypsometry, especially glacier surface elevation, give an ELA error of $\pm 150 \mathrm{~m}$. To assess the accuracy of the AABR method itself, we recalculate the modern ELA and compare it to the ELA $A_{b n}$. Because the AABR method is sensitive to hypsometry, we use a $100 \mathrm{~m}$ contour interval for both the modern calculations and the reconstructed early-mid Pliocene alpine glacier topography with this method.

The ELA reconstructed from the AABR method depends on BR (Furbish and Andrews, 1984; Kaser and Osmaston, 2002). Changes in BR over time are interpreted to reflect glacier response to climate changes (e.g. Kuhn, 1989), and BR is an established measure of the glacier-climate relationship. Typical BR values are 1.8-2.2 for glaciers in Alaska and Washington states (Meier and Tangborn, 1965; Furbish and Andrews, 1984), whereas BR values of 3-25 have been calculated for tropical glaciers (Furbish and Andrews, 1984; Kaser and Osmaston, 2002). In this study, we used the average maritime mid-latitude glacier BR value of 2.0 as a warm end-member and the present-day BR value as a cold end-member, bracketing the possible early-mid Pliocene ELA range. For each glacier we average the results from two early-mid Pliocene ELA calculations: a maximum early-mid Pliocene $E L A_{B R=1.1}$ using the current polar glacier $B R=1.1$; and a minimum $E L A_{B R=2.0}$. The MELM method yields an $E L A$ based on the elevation of lateral moraines and thus provides a minimum measure for the early-mid Pliocene ELA (Andrews, 1975).

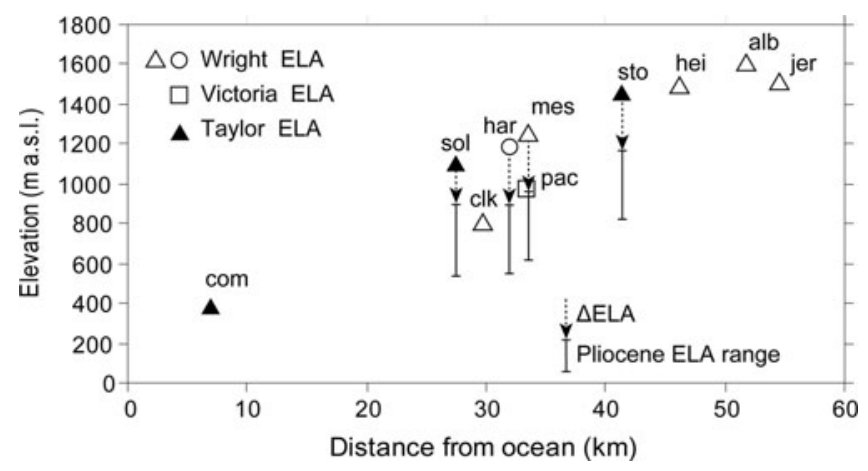

Fig. 2. Average modern and estimated early-mid Pliocene ELAs of selected Wright and Victoria Valleys (open symbols) and Taylor Valley alpine glaciers (filled symbols) with distance from the Ross Sea. Modern ELAs are based on mass-balance measurements except for Hart (har; open circle), Sollas (sol) and Stocking Glaciers (sto), which were estimated from $B R=1.1$. Commonwealth Glacier (com) ELA data are from Fountain and others (1999). Other glaciers in Wright Valley are: Clark (clk), Meserve (mes), Heimdall (hei), Alberich (alb) and Jeremy Sykes (jer). Packard Glacier (pac) in Victoria Valley is also included. Early-mid Pliocene ELAs are presented as a range adjusted for $150 \mathrm{~m}$ uplift (top) and $500 \mathrm{~m}$ uplift (bottom).

\section{RESULTS}

\section{Modern (1979-86) ELA based on mass-balance data}

ELAs for the five alpine glaciers in Wright Valley based on mass-balance measurements (e.g. Chinn, 1979, 1980, 1981, 1983) range between 795 and 1591 ma.s.l. (Table 1) and rise with increasing distance from McMurdo Sound (Fig. 2). The ELA gradient parallel to the floor of Wright Valley is $24 \mathrm{~m} \mathrm{~km}^{-1}$, only slightly lower than the gradient of $29 \mathrm{~m} \mathrm{~km}^{-1}$ that Fountain and others (1999) computed for Wright Valley.

BR values range between 0.56 and 2.45. The high BR (2.45) of Packard Glacier deviates from that of the Wright Valley glaciers. It reflects a much lower ELA which might be the result of temporary local ablation (e.g. from wind erosion, or from different climatic conditions in eastern Victoria Valley). The average BR is 1.1 , or 0.94 without the Packard Glacier ELA. The average value for AAR is 0.61 (Table 1), higher than the AAR of $0-0.40$ that Chinn (1994) proposed. The average modern ELA for the selected MDV glaciers is $1260 \mathrm{~m}$ a.s.l. (Table 1 ).

\section{Early-mid Pliocene glacier reconstruction}

The four alpine glaciers, Meserve, Hart, Solla, and Stocking, were all longer and had wider snouts at their maximum positions in the early-mid Pliocene than at present. The front of Meserve Glacier, at its maximum in the early-mid Pliocene, was situated at $200 \mathrm{~m}$ a.s.l., almost $1.2 \mathrm{~km}$ downslope from the present glacier front (Fig. 3). The glacier was also $\sim 1 \mathrm{~km}$ wider than at present, and its total area was over twice as large as today. The maximum area of Hart Glacier in the early-mid Pliocene was 30\% larger than today and had a frontal position at $225 \mathrm{~m}$ a.s.l., $900 \mathrm{~m}$ from the present glacier front (Fig. 3). Sollas Glacier at early-mid Pliocene maximum was nearly double the size of the present glacier. The snout was $50 \mathrm{~m}$ lower and $600 \mathrm{~m}$ advanced relative to today (Fig. 3). Both Hart and Sollas Glaciers were wider higher up-glacier due to the gentle lateral rock slopes. Stocking Glacier early-mid Pliocene glacier terminus was 


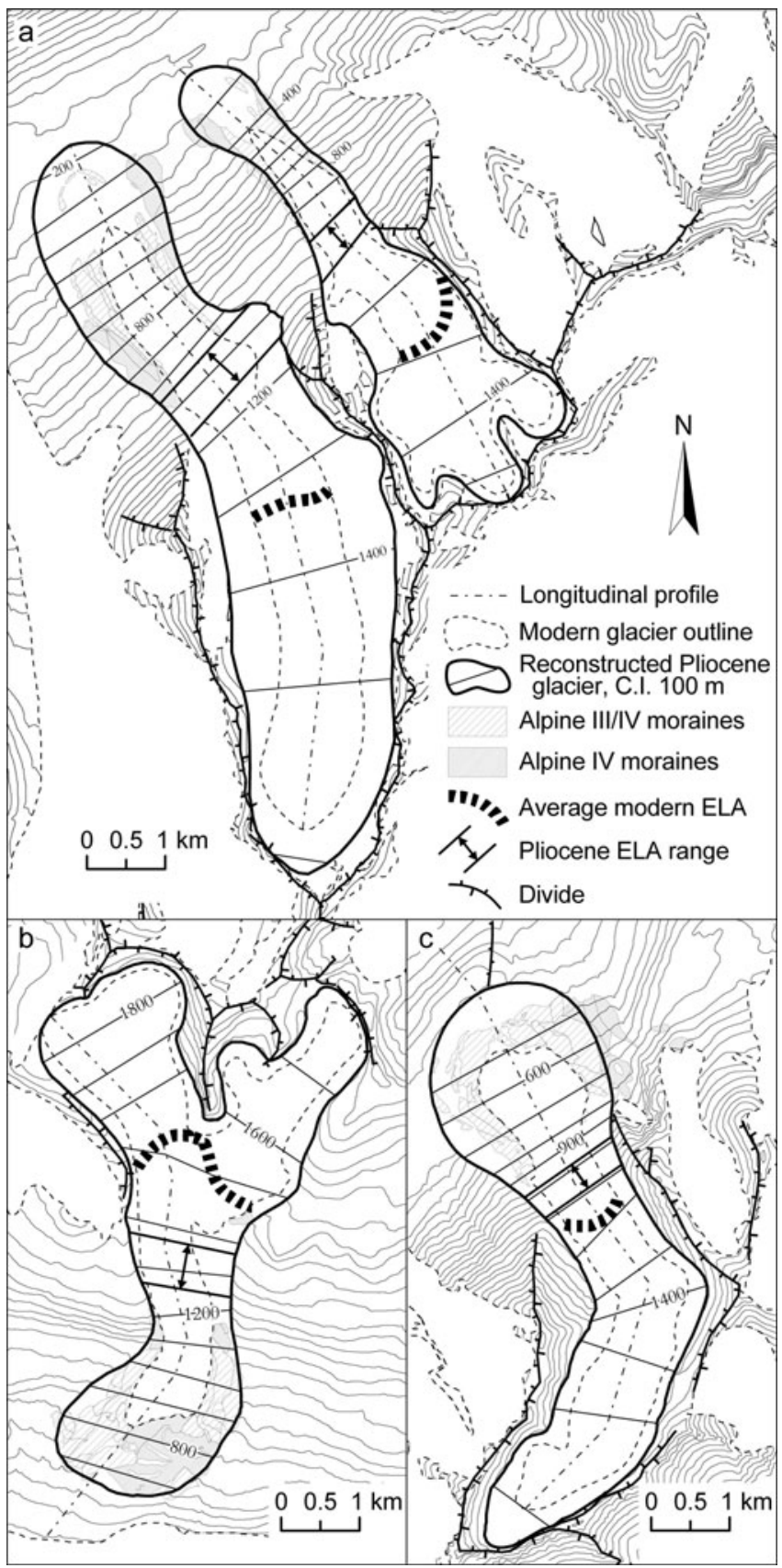

Fig. 3. Maximum extent of Meserve and Hart Glaciers, (a) Stocking Glacier (b) and Sollas Glacier (c) in the early-mid Pliocene during the Alpine IV glaciation. Reconstructed hypsometry is shown with a contour interval of $100 \mathrm{~m}$ and land topography with $50 \mathrm{~m}$. The range of early-mid Pliocene ELAs is shown with double arrow. C.I: contour interval

$1 \mathrm{~km}$ from the present terminus and $\sim 100 \mathrm{~m}$ lower (Fig. 3), and the glacier was larger by $>60 \%$ than today.

\section{Early-mid Pliocene ELA}

The average early-mid Pliocene ELA $A_{B R}$ for Meserve, Hart, Sollas and Stocking glaciers was $1124 \pm 170 \mathrm{~m}$ a.s.l. (Table 2). The error is the sum of the $\pm 18 \mathrm{~m}$ from the AABR method and the estimated $\pm 150 \mathrm{~m}$ from uncertainties in paleo-glacier hypsometry. Early-mid Pliocene AARs average 0.64 (from $E L A_{B R=1.1}$ ) and 0.71 (from $E L A_{B R=2.0}$ ). The ELA change, $\triangle \mathrm{ELA}$, between the early-mid Pliocene and today, as the difference between the early-mid Pliocene BR-derived ELA and the observed modern ELA, is $120 \mathrm{~m}$ (Table 3).
Table 2. Modern ELA for selected MDV glaciers, and ELA during their early-mid Pliocene glacial maximum, estimated with the MELM and AABR methods. Average ELA and error estimate is for the best-estimate early-mid Pliocene ELA $A_{B R}$. All elevations are ma.s.I.

\begin{tabular}{|c|c|c|c|c|c|}
\hline \multirow[t]{2}{*}{ Glacier } & \multirow{2}{*}{$\begin{array}{c}\text { Modern } \\
\text { ELA* }\end{array}$} & \multicolumn{4}{|c|}{ Early-mid Pliocene ELA estimate } \\
\hline & & ELA $_{\text {MELM }}{ }^{\dagger}$ & $\mathrm{ELA}_{\mathrm{BR}=1.1}$ & $\mathrm{ELA}_{\mathrm{BR}=2.0}$ & Average $\mathrm{ELA}_{\mathrm{BR}}$ \\
\hline Meserve & 1233 & 985 & 1158 & 1051 & 1105 \\
\hline Hart & 1197 & 925 & 1094 & 987 & 1041 \\
\hline Sollas & 1104 & 860 & 1094 & 975 & 1035 \\
\hline Stocking & 1448 & 1170 & 1363 & 1267 & 1315 \\
\hline Average & & & & & 1124 \\
\hline
\end{tabular}

*For Meserve Glacier, the modern ELA is based on mass-balance measurements. For Hart, Sollas and Stocking glaciers, modern ELA is computed using the $A A B R$ method with $B R=1.1$. Error estimated at $\pm 18 \mathrm{~m}$.

$\dagger A l l$ ELA $A_{M E L M}$ were lower than the minimum $E L A_{B R=2.0}$, likely indicating erosion of the upper parts of the lateral moraines, so this method is not very useful here.

\section{INTERPRETATION AND DISCUSSION}

\section{Modern mass balance and ELA in the MDV}

ELAs are complex and vary widely across the valleys because of strong winds, irregular topography and very low precipitation. The accumulation patterns coincide with lee sites under mountain flanks and arêtes in response to prevailing southwest winds bringing precipitation or redistributing snow. Ablation is low and mainly reflects sublimation; wind erosion also plays a role. The Wright Valley mass-balance data show that one single storm event can be significant for mass balance, a sensitivity that Fountain and others (2006) also found in Taylor Valley. The higher inland ELAs reflect warmer, drier conditions resulting from geographic blocking of maritime air.

\section{Tectonic uplift since the early-mid Pliocene}

The reconstructed ELAs should be adjusted for tectonic uplift since the early-mid Pliocene. Ishman and Rieck (1992) suggested an uplift rate of $125 \mathrm{~m} \mathrm{Ma}^{-1}$, which implies total uplift since $4 \mathrm{Ma}$ of $500 \mathrm{~m}$. Wilch and others (1993a) concluded that uplift was $<300 \mathrm{~m}$, with the possibility that there has been no uplift since the early-mid Pliocene. However, elevated early Pliocene marine sediments in the MDV show that uplift has occurred since the Pliocene (e.g. Prentice and others, 1993). Therefore, the early-mid Pliocene ELAs were adjusted for two different uplift scenarios: a moderate uplift scenario represented by an average uplift of $150 \mathrm{~m}$ (Wilch and others, 1993b); and a maximum uplift scenario of $500 \mathrm{~m}$ (Ishman and Rieck, 1992). With adjustments for uplift, the average $\Delta$ ELA since the early-mid Pliocene was 270-620 $\pm 170 \mathrm{~m}$ (Table 3).

\section{Early-mid Pliocene glaciers and climate inference}

One issue is the subglacial thermal regime. Early-mid Pliocene moraines are significantly larger than the late Pleistocene and Holocene boulder-belt moraines. The glacial sediments in hand-dug pits are coarse in texture, lack striated stones and contain ventifacts, and thus led Hall and others (1993) to infer that glaciers were as polar as today and that there has been a continuously cold climate. Because the 
Table 3. Modern ELA and ELA during early-mid Pliocene alpine glacial maximum for selected glaciers in the Dry Valleys and the $\triangle E L A$ between these two times. The early-mid Pliocene ELAs are based on the AABR method (no uplift), and adjusted for uplift scenarios of 150 and $500 \mathrm{~m}$

\begin{tabular}{|c|c|c|c|c|c|c|}
\hline \multirow[t]{3}{*}{ Glacier } & \multirow{3}{*}{$\begin{array}{c}\text { Modern ELA } \\
\text { ma.s.l. }\end{array}$} & \multicolumn{3}{|c|}{ Average early-mid Pliocene ELA } & \multicolumn{2}{|c|}{$\Delta \mathrm{ELA}$} \\
\hline & & No uplift & Uplift $150 \mathrm{~m}$ & Uplift 50 m & No uplift & Uplift 150-500 m \\
\hline & & ma.s.l. & ma.s.l. & ma.s.l. & $\mathrm{m}$ & $\mathrm{m}$ \\
\hline Meserve & 1233 & 1105 & 955 & 605 & 128 & $278-628$ \\
\hline Hart & 1197 & 1041 & 891 & 541 & 156 & $306-656$ \\
\hline Sollas & 1104 & 1035 & 885 & 535 & 69 & $219-569$ \\
\hline Stocking & 1448 & 1315 & 1165 & 815 & 133 & $283-633$ \\
\hline Wright & 1215 & 1073 & 923 & 573 & 142 & $292-642$ \\
\hline Taylor & 1276 & 1175 & 1025 & 675 & 101 & $251-601$ \\
\hline Average & 1246 & 1124 & 974 & 624 & 122 & $272-622$ \\
\hline
\end{tabular}

current sediment volumes are tiny, this seems implausible. Prentice and Krusic (2005) argued that the environment in the MDV must have been significantly different in the past to support much-expanded alpine glaciers. Although Cuffey (2000) demonstrated subglacial debris entrainment at a frozen glacier bed, this mechanism erodes and moves only small sediment volumes. Though it is not known how long it took for the early-mid Pliocene moraines to be deposited, it is possible that some of the sediments were derived subglacially from a partially thawed glacier bed. As microfossils have shown warmer sea surface temperatures, it is feasible that, for example, summer air temperatures were high enough to enable melting and glacier sliding. The climate-change mechanisms responsible for these observations would most likely involve a decrease in sublimation, and an increase in melting and accumulation. The combination of evidence of much larger early-mid Pliocene glaciers, possibly larger moraine sediment volumes, and lower early-mid Pliocene ELA than today, supports a warmer and wetter Pliocene climate. We suggest that it is possible that some of the alpine glaciers were partly wetbased in this warmer and wetter early-mid Pliocene environment.

\section{CONCLUSIONS}

In Wright Valley, present-day ELAs based on mass-balance data increase with inland distance, and averaged $795 \mathrm{~m}$ a.s.I. (Clark Glacier), 1233 m a.s.l. (Meserve), 1478 m a.s.l. (Heimdall), $1591 \mathrm{ma.s.l.}$ (Alberich) and $1500 \mathrm{~m}$ a.s.l. (Jeremy Sykes). For the above-mentioned glaciers and time, the AAR averaged 0.61 and the BR averaged 1.1.

ELAs have risen from the early-mid Pliocene to the cold and dry conditions of the present MDV by $120 \mathrm{~m}$. Considering uplift, the $\triangle E L A$ may have been 270 $620 \pm 170 \mathrm{~m}$. Uncertainties are a combination of the glacier reconstruction, where the lack of surficial geology and erosional marks in the accumulation area makes the drawing of the early-mid Pliocene glacier boundary interpretative and subjective; and within the assumption that ELA reconstructions based on parameters derived under current climate conditions are applicable in the early-mid Pliocene. We suggest that the early-mid Pliocene climate in the McMurdo Dry Valleys was warmer and wetter than previous studies of alpine glacier geology have stated.

\section{ACKNOWLEDGEMENTS}

We thank T. Chinn, the Scientific Editor, and K. MacClune for helpful editorial comments. The US National Science Foundation, under grant No. OPP96-27625, partially supported this research. We thank S. Glidden, M. Routhier, T. Brackett and N. Torbick for expert GIS support. The material was included in a thesis submitted to the Graduate School at the University of New Hampshire as part of the requirements for completion of a master's degree.

\section{REFERENCES}

Andrews, J.T. 1975. Glacial systems; an approach to glaciers and their environments. North Scituate, MA, Duxbury Press.

Ashworth, A.C. and G. Kuschel. 2003. Fossil weevils (Coleoptera: Curculionidae) from latitude $85^{\circ} \mathrm{S}$ Antarctica. Palaeogeogr., Palaeoclimatol., Palaeoecol., 191(2), 191-202.

Chinn, T.J. 1979. Hydrological research report, Dry Valleys, Antarctica 1974-75. Christchurch, New Zealand Ministry of Works and Development

Chinn, T.J. 1980. Hydrological research report, Dry Valleys, Antarctica 1970-71. Christchurch, New Zealand Ministry of Works and Development

Chinn, T.J. 1981. Hydrological research report, Dry Valleys, Antarctica 1974-75. Christchurch, New Zealand Ministry of Works and Development, Water and Soil Division. (Report WS 473.0

Chinn, T.J. 1983. Hydrology and glaciology, Dry Valleys, Antarctica annual report for 1976-77 and 1977-78. Christchurch, New Zealand Ministry of Works and Development

Chinn, T.J.H. 1991. Polar glacier margin and debris features. Mem. Soc. Geol. Ital., 46, 25-44.

Chinn, T.J. 1994. Glacier disequilibrium in the Convoy Range, Transantarctic Mountains, Antarctica. Ann. Glaciol., 20, 269-276.

Chinn, T.J. 1996. The Southern Hemisphere glacial record Antarctica and New Zealand. Pap. Proc. R. Soc. Tasmania, 130, Part 2, 17-24.

Chinn, T.J.H. and R. Cumming. 1983. Hydrology and glaciology, Dry Valleys, Antarctica: annual report for 1978-1979. Christchurch, New Zealand Ministry of Works and Development. Water and Soil Science Center. (Report WS 810.)

Chinn, T.J. and I. Maze. 1983. Hydrology and glaciology, Dry Valleys, Antarctica: annual report for 1980-1981. Christchurch, New Zealand Ministry of Works and Development. (Report WS 900.) 
Chinn, T.J. and A.K.C. Oliver. 1985. Hydrology and glaciology, Dry Valleys, Antarctica: annual report for 1982-1983. Christchurch, New Zealand Ministry of Works and Development. (Report WS 1188.)

Chinn, T. and A.D.H. Woods. 1984. Hydrology and glaciology, Dry Valleys, Antarctica: annual report for 1981-1982. Christchurch, New Zealand Ministry of Works and Development. (Report WS 1017.)

Cronin, T.M., H.J. Dowsett, G.S. Dwyer, P.A. Baker and M.A. Chandler. 2005. Mid-Pliocene deep-sea bottom-water temperatures based on ostracode $\mathrm{Mg} / \mathrm{Ca}$ ratios. Mar. MicroPalaeontol., 54(3-4), 249-261.

Cuffey, K.M. and 8 others. 2000. Entrainment at cold glacier beds. Geology, 28(4), 351-354.

Dana, G.L., R.A. Wharton, Jr and A.G. Fountain. 1996. McMurdo Dry Valleys LTER: solar radiation on glaciers in Taylor Valley, Antarctica. Antarct. J. US, 31(2), 191-193.

Denton, G.H., J.G. Bockheim, S.C. Wilson and M. Stuiver. 1989. Late Wisconsin and Early Holocene glacial history, inner Ross embayment, Antarctica. Quat. Res., 31(2), 151-182.

Denton, G.H., D.E. Sugden, D.R. Marchant, B.L. Hall and T.I. Wilch. 1993. East Antarctic ice sheet sensitivity to Pliocene climatic change from a dry valleys perspective. Geogr. Ann., 75A(4), 155-204.

Dort, W., Jr. 1970. Climatic causes of alpine glacier fluctuation, southern Victoria Land. IAHS Publ. 86 (Symposium at Hanover, NH 1968 - Antarctic Glaciological Exploration (ISAGE)), 358-362.

Dowsett, H.J., M.A. Chandler, T.M. Cronin and G.S. Dwyer. 2005. Middle Pliocene sea surface temperature variability. Paleoceanography, 20(PA2), PA2014. (10.1029/2005PA001133.)

Fountain, A.G., G.L. Dana, K.J. Lewis, B.H. Vaughn and D.M. McKnight. 1998. Glaciers of the McMurdo Dry Valleys, southern Victoria Land, Antarctica. In Priscu, J.C., ed. Ecosystem dynamics in a polar desert: the McMurdo Dry Valleys, Antarctica. Washington, DC, American Geophysical Union, 65-75. (Antarctic Research Series 72.)

Fountain, A.G., K.J. Lewis and P.T. Doran. 1999. Spatial climatic variation and its control on glacier equilibrium line altitude in Taylor Valley, Antarctica. Global Planet. Change, 22(1-4), 1-10.

Fountain, A.G., T.H. Nylen, K.L. MacClune and G.L. Dana. 2006. Glacier mass balances (1993-2001), Taylor Valley, McMurdo Dry Valleys, Antarctica. J. Glaciol., 52(178), 451-462.

Furbish, D.J. and J.T. Andrews. 1984. The use of hypsometry to indicate long-term stability and response of valley glaciers to changes in mass transfer. J. Glaciol., 30(105), 199-211.

Hall, B.L., G.H. Denton, D.R. Lux and J.G. Bockheim. 1993. Late Tertiary Antarctic paleoclimate and ice-sheet dynamics inferred from surficial deposits in Wright Valley. Geogr. Ann., 75A(4), 239-267.

Hall, B.L., G.H. Denton, D.R. Lux and C. Schluchter. 1997. Pliocene paleoenvironment and Antarctic ice sheet behavior: evidence from Wright Valley. J. Geol., 105(3), 285-294.

Holdsworth, G. and C. Bull. 1970. The flow law of cold ice: investigations on Meserve Glacier, Antarctica. IASH Publ. 86 (Symposium in Hanover, NH 1968 - Antarctic Glaciological Exploration (ISAGE)), 204-216.
Ishman, S.E. and H.J. Reick. 1992. A Late Neogene Antarctic glacio-eustatic record, Victoria Land Basin margin, Antarctica. In Kennett, J.P. and J. Barron, eds. The Antarctic paleoenvironment: a perspective on global change Part 1. Washington, DC, American Geophysical Union, 327-348. (Antarctic Research Series 56.)

Kaser, G. and H. Osmaston. 2002. Tropical glaciers. Cambridge, etc., Cambridge University Press.

Krusic, A.G. 2006. Pliocene glacial geology and climate in McMurdo Dry Valleys, Antarctica. (MS thesis, University of New Hampshire.)

Kuhn, M. 1989. The response of the equilibrium line altitude to climatic fluctuations: theory and observations. In Oerlemans, J., ed. Glacier fluctuations and climatic change. Dordrecht, etc., Kluwer Academic Publishers, 407-417.

Kurowski, L. 1891. Die Höhe der Schneegrenze mit besonderer Berücksichtigung der Finsteraarhorn-Gruppe. Berlin Geogr. Abh., 5(1), 119-160.

Lewis, A.R., D.R. Marchant, D.E. Kowalewski, S.L. Baldwin and L.E. Webb. 2006. The age and origin of the Labyrinth, western Dry Valleys, Antarctica: evidence for extensive middle Miocene subglacial floods and freshwater discharge to the Southern Ocean. Geology, 34(7), 513-516.

Marchant, D.R., G.H. Denton, C.C. Swisher, III and N. Potter, Jr. 1996. Late Cenozoic Antarctic paleoclimate reconstructed from volcanic ashes in the Dry Valleys region of southern Victoria Land. Geol. Soc. Am. Bull., 108(2), 181-194.

Meier, M.F. and W.V. Tangborn. 1965. Net budget and flow of South Cascade Glacier, Washington. J. Glaciol., 5(41), 547-566.

Osmaston, H. 1975. Models for the estimation of firnlines of present and Pleistocene glaciers. In Peel, R., M. Chisholm and P. Haggett, eds. Processes in physical and human geography. Bristol, Heinemann, 218-245.

Porter, S.C. 1975. Equilibrium-line altitudes of Late Quaternary glaciers in the Southern Alps, New Zealand. Quat. Res., 5(1), $27-47$.

Prentice, M.L. and A.G. Krusic. 2005. Early Pliocene alpine glaciation in Antarctica: terrestrial versus tidewater glaciers in Wright Valley. Geogr. Ann., 87(1), 87-109.

Prentice, M.L. and 6 others. 1993. Late Neogene Antarctic glacial history: evidence from central Wright Valley. In Kennett, J.P. and D.A. Warnke, eds. The Antarctic paleoenvironment: a perspective on global change. Part 2. Washington, DC, American Geophysical Union, 207-250. (Antarctic Research Series 60.)

Sugden, D.E. and 6 others. 1995. Preservation of Miocene glacier ice in East Antarctica. Nature, 376(6539), 412-414.

Webb, P.N., D.M. Harwood, B.C. McKelvey, J.H. Mercer and L.D. Stott. 1984. Cenozoic marine sedimentation and icevolume variation on the East Antarctic craton. Geology, 12(5), 287-291.

Wilch, T.I., G.H. Denton, D.R. Lux and W.C. McIntosh. 1993a. Limited Pliocene glacier extent and surface uplift in middle Taylor Valley, Antarctica. Geogr. Ann., 75A(4), 331-351.

Wilch, T.I., D.R. Lux, G.H. Denton and W.C. Mclntosh. 1993b. Minimal Pliocene-Pleistocene uplift of the dry valleys sector of the Transantarctic Mountains: a key parameter in ice-sheet reconstructions. Geology, 21(9), 841-844. 